\title{
Consolidated bioprocessing of butanol production from xylan by a thermophilic and butanologenic Thermoanaerobacterium sp. M5
}

Yujia Jiang ${ }^{1}$, Dong Guo ${ }^{1}$, Jiasheng Lu', Peter Dürre ${ }^{3}$, Weiliang Dong ${ }^{1,2}$, Wei Yan ${ }^{1}$, Wenming Zhang ${ }^{1,2}$, Jiangfeng $\mathrm{Ma}^{1,2}$, Min Jiang ${ }^{1,2^{*}}$ and Fengxue $\mathrm{Xin}^{1,2^{*}}$

\begin{abstract}
Background: Consolidated bioprocessing (CBP) has attracted increasing attention since it can accomplish hydrolytic enzymes production, lignocellulose degradation and microbial fermentation in one single step. Currently, biobutanol is mainly produced by mesophilic and solventogenic clostridia, such as Clostridium beijerinckii and C. acetobutylicum, which cannot directly utilize lignocellulose, an abundant, renewable and economic feedstock. Hence, metabolic construction or isolation of novel cellulolytic/hemicellulolytic and solventogenic bacteria to achieve direct butanol production from lignocellulose offers a promising alternative.

Results: In this study, a newly isolated Thermoanaerobacterium sp. M5 could directly produce butanol from xylan through $\mathrm{CBP}$ at $55^{\circ} \mathrm{C}$ via the butanol-ethanol pathway. Further genomic and proteomic analysis showed that the capabilities of efficient xylan degradation and butanol synthesis were attributed to the efficient expression of xylanase, $\beta$-xylosidase and the bifunctional alcohol/aldehyde dehydrogenase (AdhE). Process optimization based on the characteristic of AdhE could further improve the final butanol titer to $1.17 \mathrm{~g} / \mathrm{L}$ from xylan through CBP. Furthermore, a new co-cultivation system consisting of Thermoanaerobacterium sp. M5 which could release xylose from xylan efficiently and C. acetobutylicum NJ4 which possesses the capacity of high butanol production was established. This microbial co-cultivation system could improve the butanol titer to $8.34 \mathrm{~g} / \mathrm{L}$, representing the highest butanol titer from xylan through CBP.

Conclusions: A newly thermophilic and butanogenic bacterium Thermoanaerobacterium sp. M5 was isolated and key enzymes responsible for butanol production were characterized in this study. High butanol titer was obtained from xylan through process optimization. In addition, the newly set up microbial co-cultivation system, consisting of Thermoanaerobacterium sp. M5 and C. acetobutylicum NJ4, achieved the highest butanol production from xylan compared with the reported co-cultivation systems.
\end{abstract}

Keywords: n-Butanol, Xylan, Bifunctional alcohol/aldehyde dehydrogenase (AdhE), Thermoanaerobacterium, Co-cultivation

\footnotetext{
*Correspondence: bioengine@njtech.edu.cn; xinfengxue@njtech.edu.cn

1 State Key Laboratory of Materials-Oriented Chemical Engineering,

College of Biotechnology and Pharmaceutical Engineering, Nanjing Tech

University, Puzhu South Road 30\#, Nanjing 211800, People's Republic

of China

Full list of author information is available at the end of the article
} 


\section{Background}

Butanol, a four-carbon and straight-chained alcohol, is considered as a more advanced biofuel over ethanol, owing to its higher heating value [1], better intersolubility [2], lower heat of vaporization [3], higher viscosity and lower corrosivity [4]. Nowadays, biobutanol is mainly produced through traditional acetone-butanol-ethanol $(\mathrm{ABE})$ fermentation process with a typical mass ratio of 3:6:1 conducted by several mesophilic solventogenic clostridia, such as Clostridium acetobutylicum, C. beijerinckii, C. saccharobutylicum and C. saccharoperbutylacetonicum $[5,6]$. The economics of ABE fermentation is greatly affected by costly traditional feedstocks, such as starchy based materials and molasses. Lignocelluloses, such as wheat straw and sugarcane bagasse, are ideal substrates owing to their abundance, renewability and nonfood competition with human demand; however, costly pretreatment and hydrolysis techniques are required as solventogenic clostridia cannot directly utilize polysaccharides, such as cellulose/hemicellulose $[7,8]$.

Biofuel generation from cellulose/hemicellulose without supplementation of exogenous cellulases/xylanases, known as consolidated bioprocessing (CBP), is believed to reduce costs substantially compared to the process in which cellulose/hemicellulose degradation and microbial fermentation are accomplished in separate steps [9]. Although several cellulolytic/hemicellulolytic Clostridium sp. can produce ethanol from lignocellulose through CBP, such as C. cellulolyticum and C. thermocellum, no wild-type cellulolytic/hemicellulolytic Clostridium sp. can indigenously synthesize butanol directly from lignocellulose due to the lack of butanol synthetic pathway. Only through the integration of the butanol synthetic pathway into these cellulolytic/hemicellulolytic Clostridium sp., butanol production from cellulose/hemicellulose via CBP can been achieved. For instance, $0.12 \mathrm{~g} / \mathrm{L}$ of butanol was produced from crystalline cellulose after introduction of the CoA-dependent pathway by the recombinant $C$. cellulolyticum after 20 days. In addition, it should be noticed that the butanol titer by the recombinant was still maintained at low levels due to the low cellulolytic degradation rate under mesophilic conditions [10].

Compared to the mesophilic process, thermophilic processes show greater prospects in achieving CBP owing to its relatively high degradation efficiency [11, 12]. In addition, thermophilic conditions could avoid microbial contamination, decrease the cooling costs and further facilitate the downstream product recovery [13]. Currently, most wild-type thermophilic strains, such as C. thermocellum, Thermoanaerobacterium saccharolyticum and Geobacillus thermoglucosidasius, have been widely adopted for improvement of ethanol production through genetic modification. Among these thermophilic strains, $C$. thermocellum is the most well studied and shows efficient cellulose degradation; however, it cannot utilize hemicellulose, which is the second most abundant natural resource. T. saccharolyticum is another commonly used thermophilic species; however, it lacks the capability to produce butanol [14]. Through introduction of the butanol synthetic pathway in a lactatedeficient T. saccharolyticum strain, $1.05 \mathrm{~g} / \mathrm{L}$ of butanol was finally produced from $10 \mathrm{~g} / \mathrm{L}$ xylose [12]. However, butanol production from cellulose/hemicellulose by $T$. saccharolyticum has not been reported [12]. Considering the abundance of cellulose/hemicellulose and low level of butanol production, novel thermophilic strains or processes are still urgently needed to achieve high butanol production from cellulose/hemicellulose through CBP.

In this study, a thermophilic and butanogenic Thermoanaerobacterium sp. M5 was isolated and identified, which exhibited relatively high capacity of xylan degradation and butanol production through a butanol-ethanol (BE) fermentation pathway instead of the traditional $A B E$ one. Key enzymes responsible for xylan degradation and $\mathrm{BE}$ formation were also studied. Finally, a microbial co-cultivation system was set up to further improve final butanol production from xylan through CBP.

\section{Methods}

\section{Microorganism and growth media}

The bacterium was isolated from the decomposite soil collected from Laoshan Nature Park, China, and cultivated in a reduced mineral salts medium, which contained $1.0 \mathrm{~g} / \mathrm{L} \mathrm{NaCl}, 0.5 \mathrm{~g} / \mathrm{L} \mathrm{MgCl}_{2} \cdot 6 \mathrm{H}_{2} \mathrm{O}, 0.2 \mathrm{~g} / \mathrm{L}$ $\mathrm{KH}_{2} \mathrm{PO}_{4}, 0.3 \mathrm{~g} / \mathrm{L} \mathrm{NH} \mathrm{NH}_{4} \mathrm{Cl}, 0.3 \mathrm{~g} / \mathrm{L} \mathrm{KCl}$ and $0.015 \mathrm{~g} / \mathrm{L}$ $\mathrm{CaCl}_{2} \cdot 2 \mathrm{H}_{2} \mathrm{O}$. The media were also supplemented with $1 \mathrm{~mL}$ trace element solution, $1 \mathrm{~mL} \mathrm{Na} \mathrm{SeO}_{3}-\mathrm{Na}_{2} \mathrm{WO}_{4}$ solution and $3 \mathrm{~g}$ yeast extract in $1 \mathrm{~L}$ of the medium [15]. The trace element solution contains: $(\mathrm{g} / \mathrm{L}) \mathrm{FeCl}_{2} \cdot 4 \mathrm{H}_{2} \mathrm{O}$ 1.5, $\mathrm{CoCl}_{2} \cdot 6 \mathrm{H}_{2} \mathrm{O}$ 0.19, $\mathrm{MnCl}_{2} \cdot 4 \mathrm{H}_{2} \mathrm{O} \quad 0.1, \mathrm{ZnCl}_{2} \quad 0.07$, $\mathrm{Na}_{2} \mathrm{MoO}_{4} \cdot 2 \mathrm{H}_{2} \mathrm{O} 0.036, \mathrm{NiCl}_{2} \cdot 6 \mathrm{H}_{2} \mathrm{O} 0.024, \mathrm{H}_{3} \mathrm{BO}_{3} 0.006$, $\mathrm{CuCl}_{2} \cdot 2 \mathrm{H}_{2} \mathrm{O}$ 0.002. The $\mathrm{Na}_{2} \mathrm{SeO}_{3}-\mathrm{Na}_{2} \mathrm{WO}_{4}$ solution contains: $(\mathrm{g} / \mathrm{L}) \mathrm{Na}_{2} \mathrm{SeO}_{3} \cdot 5 \mathrm{H}_{2} \mathrm{O} 0.006$ and $\mathrm{Na}_{2} \mathrm{WO}_{4} \cdot 2 \mathrm{H}_{2} \mathrm{O}$ 0.008 . Beechwood xylan purchased from Sigma-Aldrich Co. Ltd. (Shanghai, China) was used as the carbon source. In addition, $20 \mathrm{mM} \mathrm{N}$-[Tris (hydroxymethyl) metyl]-2-aminopropanesulfonic acid (TES) and $10 \mathrm{mg}$ resazurin were added as the $\mathrm{pH}$ buffer agents and oxygen indicator, respectively. $0.2 \mathrm{mM} \mathrm{Na}_{2} \mathrm{~S}, 0.2 \mathrm{mM} \mathrm{L}$-cysteine and $0.5 \mathrm{mM}$ DL-dithiothretol were finally added as reductants. $40 \mathrm{~mL}$ medium was divided in $100 \mathrm{~mL}$ serum bottles purged with $\mathrm{N}_{2}$ (nitrogen), then autoclaved for $15 \mathrm{~min}$ and cooled down to room temperature. After six transfers in medium with xylan as the sole carbon source, the enriched culture was diluted $10^{5}$ times and screened 
on agar plates with the Congo red staining method. The bacteria were inoculated by a single colony from an agar plate. C. acetobutylicum NJ4 was pre-cultured for $60 \mathrm{~h}$ when OD reached 4.0-5.0. Then, strain NJ4 was inoculated into the culturing medium of strain M5 after $72 \mathrm{~h}$. The fermentation can be divided into two stages. The first is the xylan degradation stage $(0-72 \mathrm{~h})$, in which the temperature and $\mathrm{pH}$ were maintained at $55{ }^{\circ} \mathrm{C}$ and 7.5 ; the following one is the butanol production stage (72-192 h), in which the temperature and $\mathrm{pH}$ were $37^{\circ} \mathrm{C}$ and 6.0. For maintenance of the $\mathrm{pH}$, various buffers with different buffering capabilities were used in this study: citrate buffer, $\mathrm{pH}$ 4.0-6.0; PBS, pH 6.0-8.0; and glycine- $\mathrm{NaOH}$ buffer, $\mathrm{pH}$ 8.0-10.0. In addition, $\mathrm{pH}$ was adjusted every $12 \mathrm{~h}$ regularly. The sampling intervals were $24 \mathrm{~h}$ and the data were obtained for at least triplicates. The processes of enrichment, isolation and cultivation were all operated in an anaerobic chamber filled with $\mathrm{N}_{2}$ and the culture temperature maintained at $55^{\circ} \mathrm{C}$. The strain M5 was preserved in China Center for Type Culture Collection (Wuhan, China) under the deposit number of CCTCC M2017072.

\section{Identification of bacterial isolates using 165 rDNA gene sequences}

The genomic DNA of cell pellets from isolate M5 was extracted and purified with the genomic DNA of M5 as the template, and PCR amplification of the 16S rDNA genes was performed with a pair of universal bacterial primer 27 forward primer: $5^{\prime}$-AGAGTTTGATCC TGG CTCAG-3', and 1492 reverse primer: 5'-TACGGCTAC CTTGTTACGACTT- $3^{\prime}$. Then the purified PCR products were sequenced and compared to available databases using the Basic Local Alignment Search Tool (BLAST) to determine the approximate phylogeny. The nucleotide sequence of culture M5 was deposited in the GenBank under an Accession Number of MF405082.1.

\section{The draft complete genome sequencing and analysis of strain M5}

The bacterium was cultivated in mineral salts medium amended with xylose as the sole carbon source for 3 days. The genomic DNA was extracted using $\mathrm{G}^{+}$bacteria genomic DNA kit (ZOMANBIO, China). The large fragment of genomic DNA was firstly broken into small sequences with an average 300 bp by Covaris M220 (Covaris, USA), and the DNA libraries were constructed via NEBNext ${ }^{\circledR}$ UltraTM DNA Library Prep Kit for Illumina (NEB, USA). Then the draft genome was sequenced using Illumina HiSeq2500 system sequencing technology. Due to the raw reads containing spike-in and lowquality reads, the raw reads should be trimmed and filtered to obtain the clean reads for the high quality of data analysis via the Trimmomatic v0.32. Finally, filtered reads were assemble de novo through the method of de Bruijn graphs via velvet v1.2.03, and all open reading frames (ORFs) were predicted by Glimmer3 v3.02 due to the flexibility of the algorithm. Lastly, the genes were annotated through the Nucleotide collection $(\mathrm{Nr} / \mathrm{Nt})$ of NCBI and Kyoto Encyclopedia of Genes And Genomes (KEGG) databases, and constructed into metabolic pathways through KEGG.

\section{Enzymatic assays}

The activity of xylanase was determined by the 3,5-dinitrosalicylic acid (DNS) method. The $1 \mathrm{~mL}$ of culture supernatant was added in $1 \mathrm{~mL}$ PBS ( $50 \mathrm{mM} \mathrm{pH} \mathrm{6.5)}$ containing $1 \%(\mathrm{w} / \mathrm{v})$ xylan and incubated at $55{ }^{\circ} \mathrm{C}$ for $10 \mathrm{~min} .2 \mathrm{~mL}$ DNS was added to terminate the reaction and detect the content of reducing sugars. Finally, the amount of reducing sugars was calculated by measuring the increasing absorbance at $540 \mathrm{~nm}$ according to the xylose standard curve. One unit $(\mathrm{U})$ of xylanase was defined as the amount of enzyme that was able to release $1 \mu$ mol xylose per min from xylan.

$\beta$-Xylosidase activity depends on the amount of $p$-nitrophenyl $(p \mathrm{NP})$ released from $p$-nitrophenyl- $\beta$-Dxylopyranoside ( $p$ NPX). The reaction mixture contained $1 \mathrm{~mL}$ of enzyme solution and $1 \mathrm{~mL} 8 \mathrm{mM} p$ NPX in $50 \mathrm{mM}, \mathrm{pH}$ 6.5 PBS. Then the reaction was incubated at $55^{\circ} \mathrm{C}$ for $10 \mathrm{~min}$ and stopped by the addition of $1 \mathrm{~mL} 1 \mathrm{M}$ $\mathrm{Na}_{2} \mathrm{CO}_{3}$ and then the increasing absorbance at $405 \mathrm{~nm}$ measured. One unit (U) of $\beta$-xylosidase activity was defined as the amount of enzyme that releases $1 \mu \mathrm{mol}$ of $p$ NP per min from the synthetic substrate $p$ NPX.

The activity of butanol dehydrogenase (BDH) was measured by monitoring the $\mathrm{NADH}$ consumption at $340 \mathrm{~nm} .15 \mathrm{mM}$ of butyraldehyde and $0.3 \mathrm{mM} \mathrm{NADH}$ was added together in $2 \mathrm{~mL}$ PBS ( $50 \mathrm{mM}, \mathrm{pH}$ 6.0). Then, $1 \mathrm{~mL}$ cell lysate was added and the reaction initiated. The NADH-BDH activity was assayed by monitoring the reducing absorbance at $340 \mathrm{~nm}$, and the amount of reduced NADH was calculated through its standard curve. One unit (U) of BDH was defined as the amount of enzyme which consumed $1 \mu \mathrm{mol}$ NADH per minute.

\section{Characterization of key proteins by LC-MS/MS analysis}

The cells were removed by centrifugation at $12,000 \mathrm{~g}$ at $4{ }^{\circ} \mathrm{C}$ for $10 \mathrm{~min}$. The protein solution was reduced with $5 \mathrm{mM}$ dithiothreitol (DTT) for $30 \mathrm{~min}$ at $56{ }^{\circ} \mathrm{C}$ and alkylated with $11 \mathrm{mM}$ iodoacetamide (IAA) for $15 \mathrm{~min}$ at room temperature in darkness. Finally, trypsin was added at 1:50 trypsin-to-protein mass ratio for the first digestion overnight and 1:100 trypsin-to-protein mass ratio for a second $4 \mathrm{~h}$ digestion. The tryptic peptides were fractionated into fractions by high $\mathrm{pH}$ reverse-phase 
column (Agilent 300Extend $\mathrm{C}_{18} ; 5 \mu \mathrm{m}$ particles, $4.6 \mathrm{~mm}$ ID, $250 \mathrm{~mm}$ length). Briefly, peptides were first separated with a gradient of $8-32 \%$ acetonitrile $(\mathrm{pH} 9.0)$ over 60 min into 60 fractions. Then, the peptides were combined into four fractions and dried by vacuum centrifuging. The tryptic peptides were dissolved in $0.1 \%$ formic acid ( $\mathrm{v} / \mathrm{v}$, solvent $\mathrm{A})$ and directly loaded onto a homemade reversed-phase analytical column (15-cm length, $75 \mu \mathrm{m}$ i.d.). The gradient comprised an increase from 6 to $25 \%$ solvent B $(0.1 \%$ formic acid in $90 \%$ acetonitrile) for $24 \mathrm{~min}$, and ramped to $25-40 \%$ solvent $\mathrm{B}$ in $8 \mathrm{~min}$, then climbing to $80 \%$ solvent $\mathrm{B}$ for $4 \mathrm{~min}$ and lastly holding at $80 \%$ solvent B for $4 \mathrm{~min}$. The flow rate was maintained at $380 \mathrm{~nL} / \mathrm{min}$ on an EASY-nLC 1000 UPLC system. The resolved peptides were subjected to NSI source followed by tandem mass spectrometry (MS/MS) in Q Exactive ${ }^{\mathrm{TM}}$ Plus (Thermo) coupled online to the UPLC. The resulting MS/MS data were processed using Maxquant search engine (v1.5.2.8).

\section{Cloning, expression and purification of a bifunctional alcohol/aldehyde dehydrogenase (AdhE)}

The adhE gene from strain M5 was amplified using the primers F/R (F: 5'-TAAGAAGGAGATATACCATGG GCCAAATAGACGCAATAGTAAAGGCAATGGC-3'; R: 5'-GTGGTGGTGGTGGTGCTCGAGTGCACCGTA TGCTTTTCTGTAGATCTC-3') and PrimeSTAR ${ }^{\circledR}$ HS DNA Polymerase (TaKaRa, Shanghai, China). The PCR conditions were: denatured at $95^{\circ} \mathrm{C}$ for $10 \mathrm{~min}$, followed by 30 cycles of $98{ }^{\circ} \mathrm{C}$ for $10 \mathrm{~s}, 55^{\circ} \mathrm{C}$ for $15 \mathrm{~s}$, and $72{ }^{\circ} \mathrm{C}$ for $2 \min 40 \mathrm{~s}$, then $72{ }^{\circ} \mathrm{C}$ for $10 \mathrm{~min}$. PCR fragment and plasmid of pET28a (+) were digested using Xho I and Nco I and ligated using One Step Cloning Kit (Vazyme Biotech. Co., Ltd., Nanjing, China). The plasmids harboring adhE gene fragment were transformed into E. coli BL21 (DE3), which was incubated in LB medium with $30 \mu \mathrm{g} /$ $\mathrm{mL}$ of kanamycin at $37^{\circ} \mathrm{C}$ for $12 \mathrm{~h} .0 .05 \mathrm{mM}$ isopropyl$\beta$-D-thiogalactopyranoside (IPTG) was added and the culture temperature was lowered to $18{ }^{\circ} \mathrm{C}$ for $20 \mathrm{~h}$. The recombinant protein with $\mathrm{His}_{6}$-tags was purified with $\mathrm{Ni}^{2+}-\mathrm{NTA}$ resin (Qiagen, Valencia, CA, USA). After elution of non-target proteins with $25 \mathrm{mM}$ imidazole in $20 \mathrm{mM}$ PBS (pH 7.0), the target fusion protein was eluted with a linear concentration gradient of imidazole in $20 \mathrm{mM}$ PBS (pH 6.0). The proteins were identified using sodium dodecyl sulfate polyacrylamide gel electrophoresis (SDS-PAGE) and visualized by staining with Coomassie Brilliant Blue R-250. SDS-PAGE was performed on a $12 \%$ gel using electrophoresis apparatus at $80 \mathrm{~V}$ for the first $60 \mathrm{~min}$, followed by $120 \mathrm{~V}$ for $2 \mathrm{~h}$.

The optimal reaction $\mathrm{pH}$ was assessed at $55{ }^{\circ} \mathrm{C}$ using the following buffers: $20 \mathrm{mM}$ citrate buffer, $\mathrm{pH} 4.0-6.0$; $20 \mathrm{mM}$ PBS, pH 6.0-8.0; and $20 \mathrm{mM}$ glycine- $\mathrm{NaOH}$ buffer, $\mathrm{pH}$ 8.0-10.0. The effect of the temperature on $\mathrm{BDH}$ activity was determined under the optimal $\mathrm{pH}$ at temperatures ranging from 35 to $85^{\circ} \mathrm{C}$. To measure the $\mathrm{pH}$ stability, the enzyme was incubated at $4{ }^{\circ} \mathrm{C}$ for $1 \mathrm{~h}$ in different buffers and the residual activity was determined using the enzyme assay conditions described above. The thermal stability of BDH was assessed by incubating the enzyme preparations at different temperatures for a certain time until the remaining activity decreased below $30 \%$ of its initial activity. Non-heated enzyme was used as the control (100\%).

\section{Analytic methods}

Concentrations of xylose were quantified by high-performance liquid chromatography (HPLC) (UitiMate 3000 HPLC system, Dionex, USA) at a wavelength of $215 \mathrm{~nm}$ on a UVD 170U ultraviolet detector, and an ion exchange chromatographic column (Bio Rad Aminex HPX-87H column, USA) was used. The products were eluted at $55{ }^{\circ} \mathrm{C}$ with $5 \mathrm{mM} \mathrm{H}_{2} \mathrm{SO}_{4}$ as the mobile phase at a flow rate of $0.6 \mathrm{~mL} / \mathrm{min}$. Metabolic products, such as ethanol, acetate, butanol and butyrate, ware detected by gas chromatography (GC-2010, Shimadzu Scientific Instruments, Japan) equipped with an InterCap WAX column $(0.25 \mathrm{~mm} \times 30 \mathrm{~m}$, GL Sciences Inc., Japan $)$ and a flame ionization detector (FID). The column temperature was held at $60{ }^{\circ} \mathrm{C}$ for $2 \mathrm{~min}$ and increased to $150{ }^{\circ} \mathrm{C}$ at a rate of $30^{\circ} \mathrm{C} / \mathrm{min}$. The temperature of the injector and detector was both set at $180{ }^{\circ} \mathrm{C}$. Nitrogen was used as the carrier gas, with a flow rate of $30 \mathrm{~mL} / \mathrm{min}$. All samples were centrifuged at $12,000 \mathrm{~g}$ for $5 \mathrm{~min}$ at $4{ }^{\circ} \mathrm{C}$, then $50 \mu \mathrm{L} \mathrm{HCl}$ $(2 \mathrm{M})$ was added in $950 \mu \mathrm{L}$ of the samples. Isobutanol was used as the internal standard.

\section{Results}

Isolation and phylogenetic identification of a thermophilic Thermoanaerobacterium sp. M5 capable of synthesizing butanol through the BE pathway

An anaerobic colony named M5 with relatively high activity of xylanase was identified on agar plates using beechwood xylan as the sole carbon source at $55^{\circ} \mathrm{C}$. Further fermentation without $\mathrm{pH}$ adjustment using mineral salts medium spiked with $20 \mathrm{~g} / \mathrm{L}$ of beechwood xylan as the sole carbon source was carried out for 5 days. After comprehensive detection with GCFID and HPLC, the final metabolic products contained $0.76 \mathrm{~g} / \mathrm{L}$ of ethanol, $0.23 \mathrm{~g} / \mathrm{L}$ of butanol, $3.49 \mathrm{~g} / \mathrm{L}$ of acetate and $4.84 \mathrm{~g} / \mathrm{L}$ of butyrate, indicating that strain $\mathrm{M} 5$ could directly synthesize butanol from xylan through CBP. Meanwhile, the elimination of acetone suggests that strain M5 may possess a BE pathway. Further phylogenetic analysis of the $16 \mathrm{~S}$ rDNA gene (NCBI Accession Number MF405082.1) showed that strain 
M5 belonged to Thermoanaerobacterium sp. with 99\% similarity with $T$. thermosaccharolyticum KKU19 (NCBI Accession Number JN020648.1) (Table 1).

Thermoanaerobacterium sp. has been reported to be a group of endospores, forming motile, rod-shaped and obligate anaerobic prokaryotes, which are broadly used for hydrogen production [16]. However, few studies regarding butanol production directly from xylan by thermophilic $T$. thermosaccharolyticum have been reported. Therefore, this newly isolated wild-type butanogenic Thermoanaerobacterium sp. M5 further broadens our knowledge and adds to the pool of known butanol-generating microbes.

Genomic sequencing, annotation and comparison of strain M5 with other thermophilic and solventogenic strains

To better understand the genomic information and elaborate the xylan degradation and butanol synthetic pathways, the whole genome of Thermoanaerobacterium sp. M5 was sequenced and annotated. The genomic sequence of strain M5 was deposited under the GenBank Accession No. of NDHF00000000. The final assembly of the genome generates 79 contigs ranging from 525 to 225947 bases with $33.9 \% \mathrm{G}+\mathrm{C}$ content, 7 rRNAs and 55 tRNAs. Strain M5 consists of an approximate $2.64 \mathrm{Mbp}$ chromosome, which is lower than those of other thermophilic sp., such as $3.84 \mathrm{Mbp}$ of C. thermocellum and $3.87 \mathrm{Mbp}$ of G. thermoglucosidasius. The 2.64 Mbp chromosome of strain M5 is only slightly lower than $2.79 \mathrm{Mbp}$ of $T$. thermosaccharolyticum DSM 571 and $2.73 \mathrm{Mbp}$ of T. saccharolyticum, and higher than $2.31 \mathrm{Mbp}$ of T. mathranii. However, it possesses more coding sequences (CDS, 2622) than those of T. thermosaccharolyticum DSM 571 (2568) and T. mathranii (2152), and similar to that of T. saccharolyticum (2643).
LC-MS/MS analysis of key enzymes involved in xylan degradation within Thermoanaerobacterium sp. M5

Although solventogenic Clostridium sp. contains some polysaccharides degrading genes, such as cellulase and xylanase, they cannot directly utilize lignocellulose due to the expression of these enzymes [17]. Currently, $T$. saccharolyticum was the most efficient xylan degrader with ethanol as the metabolic product [14]. In this study, the newly isolated Thermoanaerobacterium sp. M5 cannot only efficiently degrade up to $90 \mathrm{~g} / \mathrm{L}$ of xylan, but also produce both butanol and ethanol as final metabolic products. Furthermore, strain M5 could efficiently secrete xylan-degrading enzymes, such as xylanase and $\beta$-xylosidase to hydrolyze xylan. For example, when $30 \mathrm{~g} / \mathrm{L}$ of xylan was adopted as the sole carbon source, strain M5 could secrete $0.26 \mathrm{U} / \mathrm{mg}$ of xylanase and $3.81 \mathrm{U} / \mathrm{mg}$ of $\beta$-xylosidase in the fermentation broth after $48 \mathrm{~h}$, suggesting that strain M5 could efficiently secrete xylan-degrading enzymes.

To further identify xylan hydrolytic enzymes, proteins in the fermentation supernatant using xylan as the sole carbon source were collected. After being subjected to trypsin digestion, the samples were analyzed by LC-MS/ MS. Based on the resulting MS/MS data evaluated by the Uniprot $T$. thermosaccharolyticum database, glycoside hydrolases, mainly xylanase, xylosidase, glucuronidase and alpha-galactosidase were identified (Table 2). Among these proteins, one xylanase (D9TMZ9) and two $\beta$-xylosidases (D9TMZ0 and D9TMY9) were annotated, which are synergistically responsible for xylan degradation [18]. The domain architecture of D9TMZ9 consists of CBM4-GH10-CBM9-CBM9-SLH-SLH-SLH, which possesses 1288 amino acids with $141.5 \mathrm{kDa}$ molecular masses. According to the unique peptides, D9TMZ9 contains three main domains: carbohydrate-binding modules (CBMs), GH10 domain and the SLH (for S-layer homology) domain. The GH10 domain plays a vital role in the degradation of xylan, which implements the random hydrolysis of internal $\beta-(1,4)$-xylosidic linkages in the

Table 1 Top matches of the 16S rDNA sequence of strain M5 against known bacterial sequences from the Genbank database (BLAST, NCBI)

\begin{tabular}{|c|c|c|c|}
\hline Bacterium & Accession & Query cover (\%) & Identify (\%) \\
\hline T. thermosaccharolyticum strain JCA-5637 16S ribosomal RNA, partial sequence & LC127099.1 & 99 & 99 \\
\hline T. thermosaccharolyticum strain KKU19 16S ribosomal RNA gene, partial sequence & JN020648.1 & 99 & 99 \\
\hline T. thermostercoris strain Buff $16 \mathrm{~S}$ ribosomal RNA gene, partial sequence & NR_122103.1 & 98 & 99 \\
\hline Thermoanaerobacterium sp. K162C $16 \mathrm{~S}$ ribosomal RNA gene, partial sequence & HQ840649.2 & 99 & 98 \\
\hline T. thermosaccharolyticum M0795, complete genome & CP003066.1 & 99 & 98 \\
\hline T. thermosaccharolyticum strain DSM 571 16S ribosomal RNA, partial sequence & NR_074419.1 & 99 & 98 \\
\hline Thermoanaerobacterium sp. M5 (this study) & MF405082.1 & 100 & 100 \\
\hline
\end{tabular}


Table 2 Secreted proteins of Thermoanaerobacterium sp. M5 identified by LC-MS/MS

\begin{tabular}{|c|c|c|c|c|}
\hline Protein accession & Description & Gene name & MW [kDa] & $\begin{array}{l}\text { \#Unique } \\
\text { peptides }\end{array}$ \\
\hline D9TMZ9 & Beta-xylanase & Tthe_0992 & 141.45 & 12 \\
\hline D9TMZ0 & Xylan 1,4-beta-xylosidase & Tthe_0983 & 58.468 & 1 \\
\hline D9TMY9 & Xylan 1,4-beta-xylosidase & Tthe_0982 & 76.957 & 7 \\
\hline D9TMY6 & Xylan alpha-1,2-glucuronidase & Tthe_0979 & 78.844 & 12 \\
\hline D9TLK2 & Glucan 1,4-alpha-glucosidase & Tthe_0773 & 78.399 & 12 \\
\hline D9TNZ0 & Alpha-galactosidase & Tthe_0140 & 83.958 & 1 \\
\hline D9TR57 & Beta-glucosidase & Tthe_1813 & 51.651 & 7 \\
\hline P29441 & Xylose isomerase & xylA & 50.183 & 21 \\
\hline D9TTQ7 & Xylulokinase & Tthe_2491 & 54.684 & 5 \\
\hline D9TMP1 & Aldehyde-alcohol dehydrogenase & Tthe_2646 & 94.723 & 11 \\
\hline D9TP56 & Iron-containing alcohol dehydrogenase & Tthe_1156 & 43.352 & 11 \\
\hline D9TR64 & Iron-containing alcohol dehydrogenase & Tthe_1821 & 39.632 & 3 \\
\hline D9TSE3 & Iron-containing alcohol dehydrogenase & Tthe_0472 & 42.453 & 6 \\
\hline D9TTR6 & Iron-containing alcohol dehydrogenase & Tthe_2500 & 43.298 & 6 \\
\hline
\end{tabular}

insoluble xylan backbone to soluble xylooligosaccharides [19]. The GH10 domain in D9TMZ9 possesses 276 amino acids with the predicted $31.4 \mathrm{kDa}$ molecule mass and a $(\beta / \alpha)_{8}$-fold structure. In addition, the CBMs are distinct in their selectivity for binding amorphous lignocellulose, and SLHs are paracrystalline mono-layered assemblies of (glyco)proteins, which coat the surface of bacteria with about 50-60 residues. These two domains facilitate the combination with xylan and promote xylan degradation. The two identified xylosidases, D9TMZ0 and D9TMY9, belong to GH39 and GH52, respectively, with the predicted molecular weights of 58.5 and $77.0 \mathrm{kDa}$, which could further hydrolyze the terminal xylose monomers from the non-reducing end of xylooligosaccharides.

\section{Identification and characterization of AdhE enzyme from Thermoanaerobacterium sp. M5}

AdhE is the key enzyme in solventogenic strains responsible for the catalysis of CoA into solvents. Generally, solventogenic clostridia possess two AdhE (AdhE1 and AdhE2) [20]. However, only one $a d h E$ was annotated in the genome of strain M5 with predicted molecular mass of $94.7 \mathrm{kDa}$, which was also identified by LC-MS/MS (D9TMP1). Furthermore, no aldehyde dehydrogenase (ALDH) within the annotated CDS of strain M5 was identified, which generally could reduce acetyl-CoA/ butyryl-CoA to acetaldehyde/butyraldehyde, proving that $a d h E$ was the only crucial enzyme for BE production. Actually, deletion of adhE in Thermoanaerobacterium sp. could lead to the elimination of solvent production [20]. Further bioinformatic analysis showed that AdhE from strain M5 was divided into two domains, ALDH and alcohol dehydrogenase (ADH), which were connected by a conserved linker sequence, indicating it may play biofunction in BE production (Fig. 2a). The ALDH domain is located at the $\mathrm{N}$-terminal, while the $\mathrm{ADH}$ domain is located at the $\mathrm{C}$-terminal, which is iron dependent. Both $\mathrm{ALDH}$ and $\mathrm{ADH}$ possess an NADH binding site, and the two domains are connected by a small conserved linker sequence containing a GXGXXG motif and a putative nucleotide binding region (Fig. 1) [2, 21]. Through the blast of protein data bank archive (pdb) database in the NCBI website, a putative $\mathrm{Fe}^{2+}$ binding site is further identified in the ADH domain, suggesting that supplementation of $\mathrm{Fe}^{2+}$ may help improve AdhE activity and butanol production.

To better characterize this enzyme, $a d h E$ was successfully expressed in E. coli BL21 (DE3) and purified using $\mathrm{Ni}^{2+}$-NTA resin. SDS-PAGE (12\%) showed that the molecular weight of AdhE was approximately $95 \mathrm{kDa}$, which is similar to the predicted $94.7 \mathrm{kDa}$. Especially, the recombinant AdhE possessed a high $\mathrm{BDH}$ activity of $76.31 \mathrm{U} / \mathrm{mg}$, which is higher than $18.07 \mathrm{U} / \mathrm{mg}$ of $\mathrm{BDH}$ from C. ljungdahlii and $0.18 \mathrm{U} / \mathrm{mg}$ of AdhE2 from C. acetobutylicum $[22,23]$. The recombinant AdhE displayed its maximum $\mathrm{BDH}$ activity at $55^{\circ} \mathrm{C}$; it also exhibited more than $90 \%$ of maximum $\mathrm{BDH}$ activity between 50 and $65^{\circ} \mathrm{C}$ (Fig. 2b (3)). Thermostability analysis showed that AdhE retained more than $90 \%$ of activity at $55{ }^{\circ} \mathrm{C}$ for nearly $4 \mathrm{~h}$ (Fig. 2b (4)), suggesting that AdhE is thermostable [24]. On the other hand, AdhE exerted high levels of activity at a wide $\mathrm{pH}$ range of 6.5-8.5; however, almost no activities were detected at $\mathrm{pH}$ below 4.0 or above 9.5 (Fig. 2b (1)). pH stability assays showed that the purified enzyme retained more than $70 \%$ of its activity at $\mathrm{pH} 6.0-$ 8.5 for $20 \mathrm{~h}$, whereas its stability decreased significantly at 


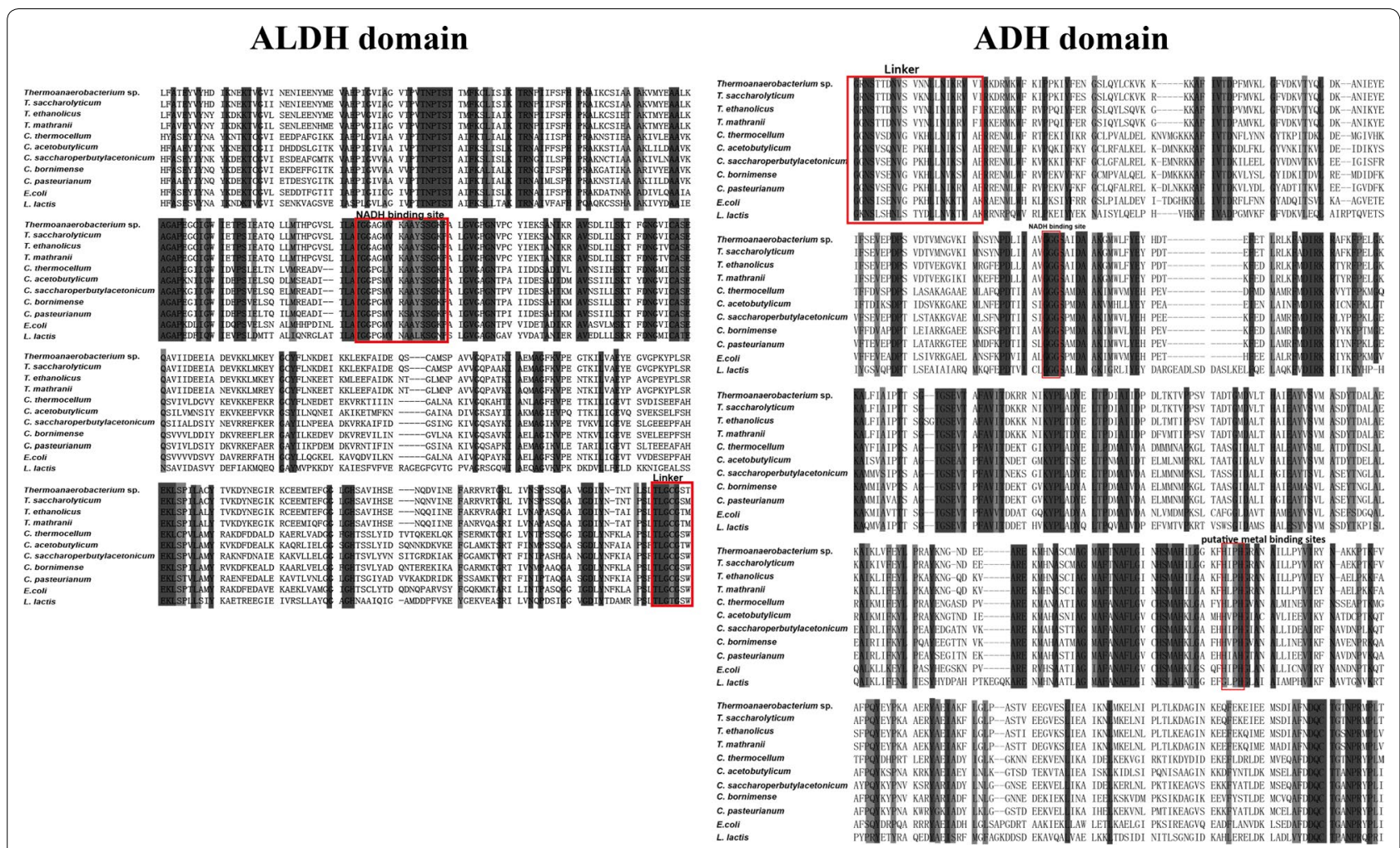

Fig. 1 Characterization of butanol-catalyzing and thermostable AdhE enzyme of Thermoanaerobacterium sp. M5. The results of blasting various AdhE from different strains. (1) Determination of the optimum pH. Error bars correspond to the standard deviation of three measurements

pH values below pH 6.0 or above pH 9.0 (Fig. 2b (2)). The data shown here could further guide the process optimization for improvement of butanol production.

\section{Improvement of butanol production through process optimization}

$\mathrm{pH}$ has been proved to be a key factor in the ABE fermentation process, and generally solventogenic Clostridium sp. shows a bi-phase fermentation mode, which includes acidogenic and solventogenic phases. Part of acids formed in the acid phase will be re-assimilated for further solvent production, accompanied by the rebounce of $\mathrm{pH}$ values [25]. However, strain M5 did not show the typical bi-phase fermentation mode, in which acids (acetate and butyrate) and solvents (ethanol and butanol) constantly increased along with the fermentation duration. $\mathrm{pH}$ optimization experiments showed that slight alkaline environment at $\mathrm{pH} 7.5$ is more suitable for butanol production, which is completely different from the reported acidic environment at $\mathrm{pH} 4.5-5.5$ using solventogenic clostridia (Table 3) [26]. This is consistent with our finding that the optimum $\mathrm{pH}$ for $\mathrm{BDH}$ activity is between 6.5 and 8.5 (Fig. 2b). $0.60 \mathrm{~g} / \mathrm{L}$ of butanol was finally obtained from $30 \mathrm{~g} / \mathrm{L}$ of xylan, which showed almost 100\% increase compared to the one without $\mathrm{pH}$ control. When strain M5 was cultivated under the $\mathrm{pH}$ values below 6.0 or above 9.0 , less than $0.10 \mathrm{~g} / \mathrm{L}$ of butanol occurred.

Reducing power has been reported as a limiting factor for reductive chemicals synthesis, such as butanol [27]. Furthermore, BDH was characterized as $\mathrm{NAD}(\mathrm{P}) \mathrm{H}$ dependent. Hence, to further drive metabolic flux toward butanol synthesis, artificial electron carriers (AEC), such as neutral red (NR) and methyl viologen (MV), were supplemented in the fermentation initially. As seen in Fig. 3a, when NR was increased to $0.6 \mathrm{mM}$, butanol production was significantly improved from 0.60 to $0.93 \mathrm{~g} / \mathrm{L}$. Meanwhile, the amount of butyrate was decreased when NR was increased from 0.1 to $0.8 \mathrm{mM}$, suggesting that the carbon flux may be altered toward butanol production through CoA-transferase. However, the supplementation of MV gave even lower butanol production (Fig. 3b), which may be because MV inhibits bacterial growth [28].

Some divalent ions, such as $\mathrm{Fe}^{2+}, \mathrm{Ca}^{2+}$ and $\mathrm{Zn}^{2+}$, also influence butanol production [29-31]. Figure 3c shows that the addition of $\mathrm{CaCl}_{2}(0.5-6.0 \mathrm{~g} / \mathrm{L})$ did not help 


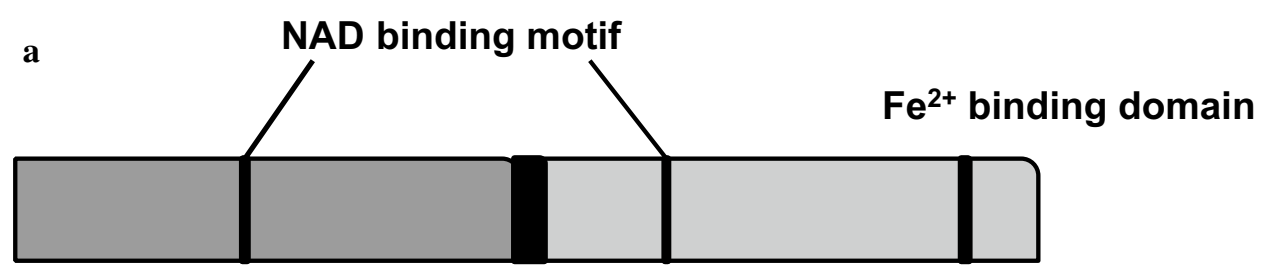

\section{ALDH domain linker $\quad$ ADH domain}

(1)

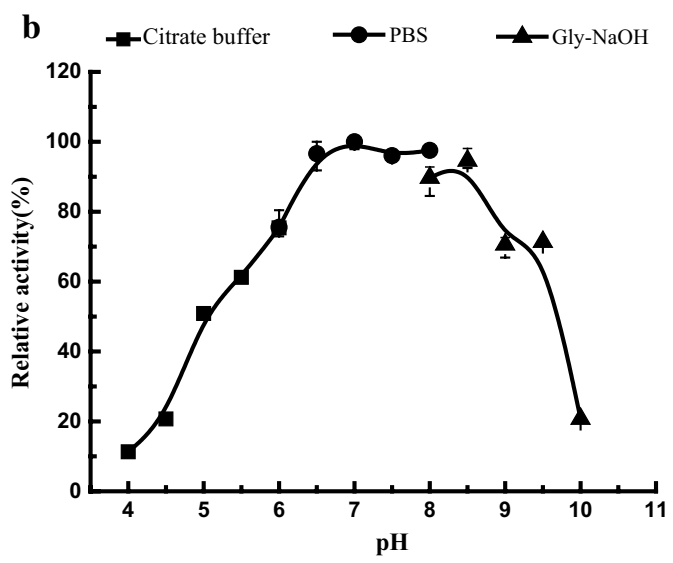

(3)

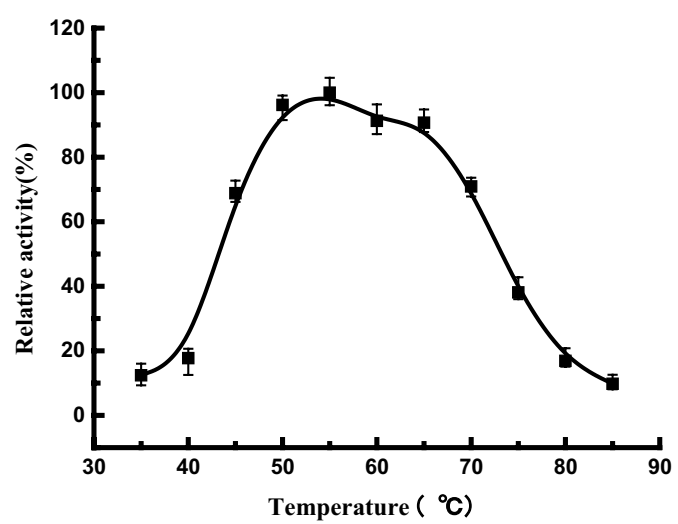

(2)

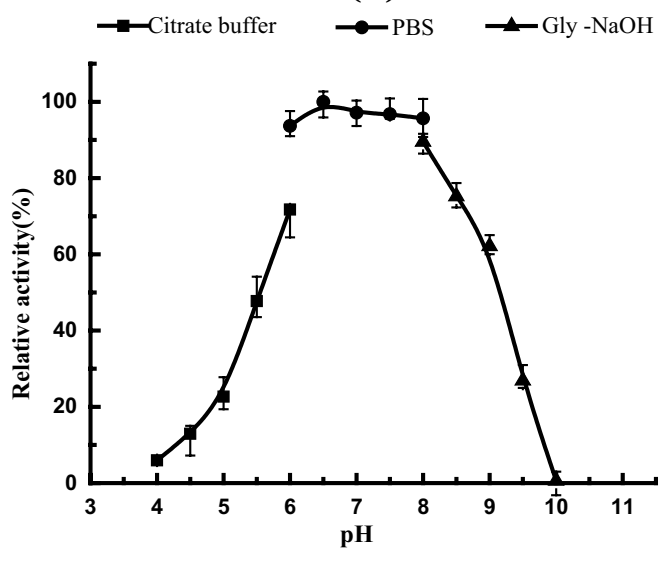

(4)

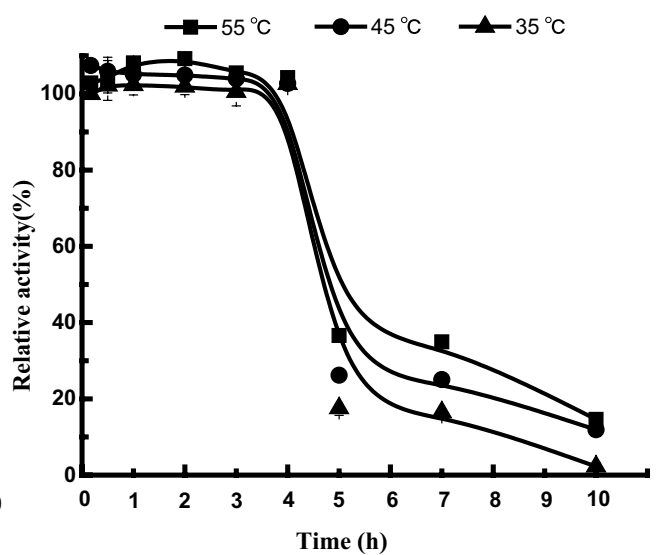

Fig. 2 Characterization of butanol-catalyzing and thermostable AdhE enzyme of Thermoanaerobacterium sp. M5. a The predicted structure of AdhE. $\mathbf{b}$ Effects of temperature and pH on enzyme activity and stability. Determination of (1) the optimum pH; (2) pH stability; (3) the optimum temperature; (4) thermal stability. Error bars correspond to the standard deviation of three measurements

boost butanol production, and the addition of $\mathrm{ZnCl}_{2}$ even lowered butanol production (Fig. 3d). On the contrary, the addition of $\mathrm{FeCl}_{2}$ in the culture could obviously enhance butanol production. The highest butanol production of $1.17 \mathrm{~g} / \mathrm{L}$ was achieved with supplementation of $0.05 \mathrm{~g} / \mathrm{L} \mathrm{FeCl}_{2}$ in the culture, which was almost twofold higher than that of the control groups (Fig. 3e).
High butanol production by co-cultivation of Thermoanaerobacterium sp. M5 and C. acetobutylicum NJ4

Thermoanaerobacterium sp. M5 could efficiently degrade up to $90 \mathrm{~g} / \mathrm{L}$ of xylan; however, the final butanol titer was not improved significantly and a high amount of reducing sugars was still left over in the fermentation broth. Hence, 


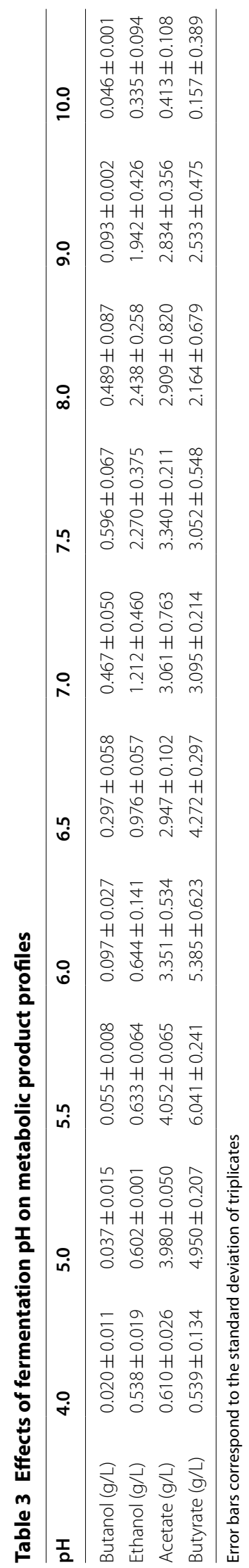



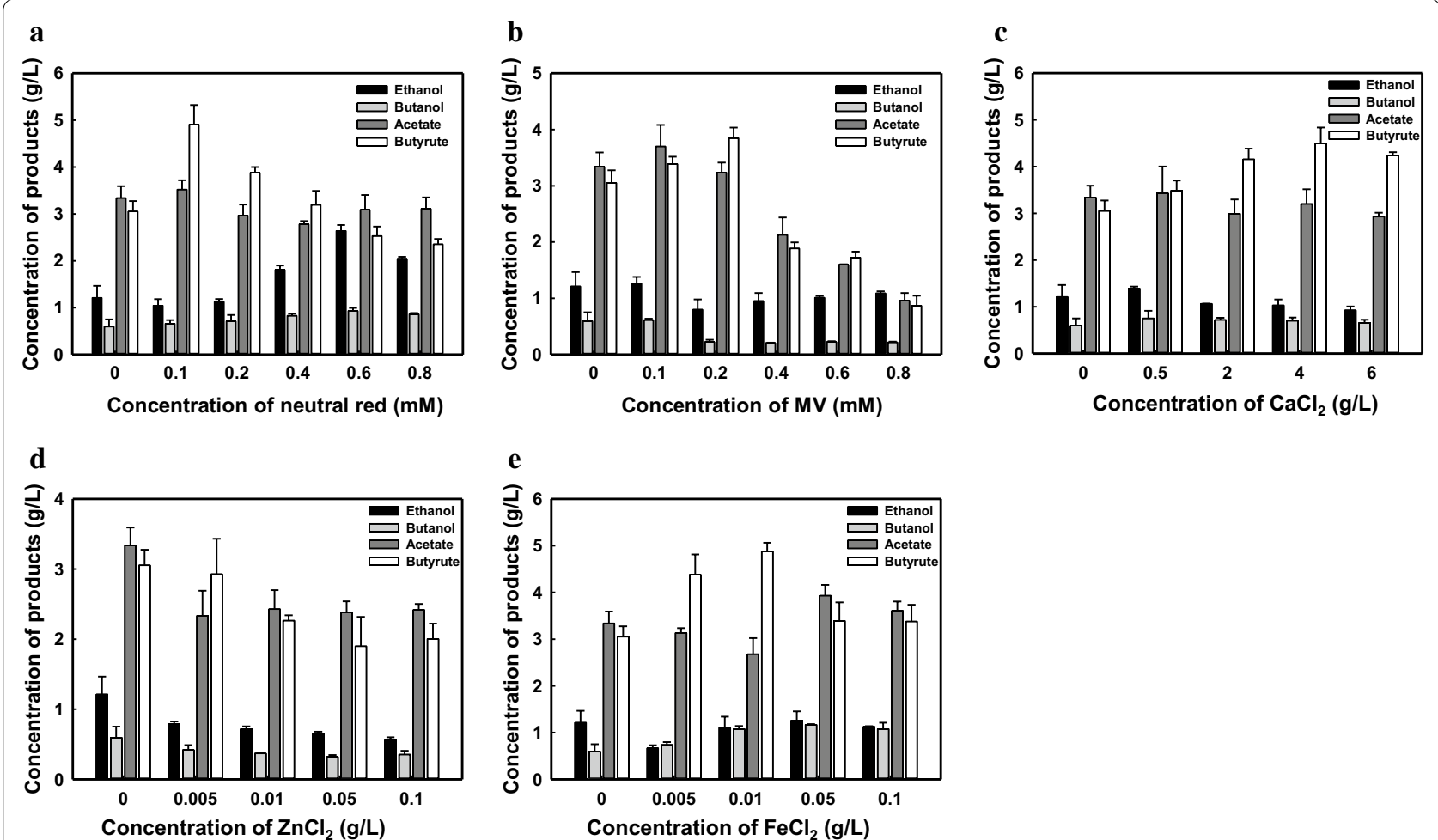

Fig. 3 Effects of different AECs and divalent ions on butanol production for Thermoanaerobacterium sp. M5. Fermentation profiles of Thermoanaerobacterium sp. M5 in medium containing a NR, b MV, c CaCl, $\mathbf{d ~} \mathrm{ZnCl}_{2}$, e FeCl 2 . Error bars correspond to the standard deviation of three measurements

to further improve the final butanol titer, a one step process by co-cultivation of Thermoanaerobacterium sp. M5 and C. acetobutylicum $\mathrm{N} 44$ was set up for improvement of butanol production. In this co-cultivation system, Thermoanaerobacterium sp. M5 was firstly grown on $60 \mathrm{~g} / \mathrm{L}$ of beechwood xylan at $55^{\circ} \mathrm{C}$, and $0.58 \mathrm{U} / \mathrm{mL}$ xylanase and
$7.69 \mathrm{U} / \mathrm{mL} \beta$-xylosidase were secreted into the culture medium (Fig. 4a). The xylan-degrading enzymes could readily hydrolyze xylan into xylose in the culture medium and low levels of ethanol $(1.11 \mathrm{~g} / \mathrm{L})$, butanol $(0.78 \mathrm{~g} / \mathrm{L})$, acetic acid $(3.47 \mathrm{~g} / \mathrm{L})$ and butyric acid $(4.41 \mathrm{~g} / \mathrm{L})$ were synthesized within $72 \mathrm{~h}$ (Fig. 4b). Subsequently, the
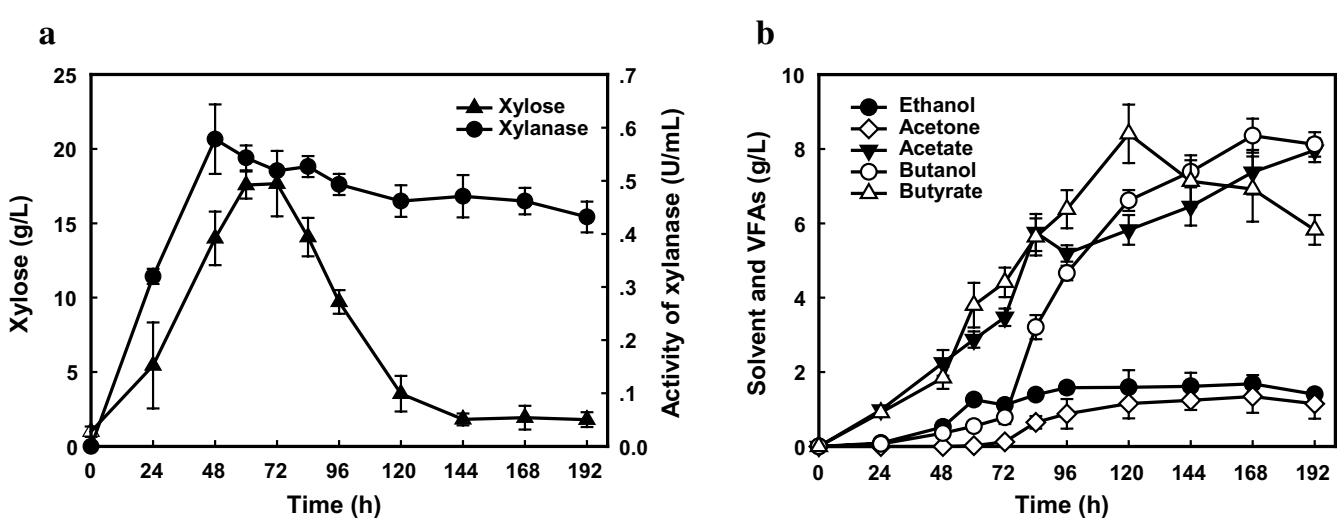

Fig. 4 Fermentaion profiles using a co-cultivation system consisting of Thermoanaerobacterium sp. M5 and C. acetobutylicum NJ4. a Time-dependent enzyme activities, xylose concentration and $\mathbf{b}$ product concentrations in the co-cultivation system consisting of culture Thermoanaerobacterium sp. M5 and C. acetobutylicum NJ4 from $60 \mathrm{~g} / \mathrm{L}$ beechwood xylan 
solventogenic C. acetobutylicum NJ4 isolated by our laboratory was further inoculated into Thermoanaerobacterium sp. M5 culture medium. As seen in Fig. 4a, xylanase and $\beta$-xylosidase activities were still relatively stable in the culture medium after the incubation of strain NJ4, indicating that active enzymes still performed hydrolytic functions for continuous hydrolysis of xylan to fermentable reducing sugars. More importantly, the addition of C. acetobutylicum NJ4 to the Thermoanaerobacterium sp. M5 culture boosted utilization of xylose accumulated in the medium and gave a high $1.68 \mathrm{~g} / \mathrm{L}$ of ethanol and $8.34 \mathrm{~g} / \mathrm{L}$ of butanol, corresponding to a butanol and solvent yield of 0.14 and $0.17 \mathrm{~g} / \mathrm{g}$, respectively. The high initial xylose concentration $(17.6 \mathrm{~g} / \mathrm{L})$, constantly stable xylanase activity $(\sim 0.5 \mathrm{U} / \mathrm{mL})$ and high butyric acid concentration $(3.8 \mathrm{~g} / \mathrm{L})$ may contribute to butanol formation after inoculation of culture NJ4. Results in this study demonstrated the potential of converting lignocellulosic substrates directly to fuels by using this co-cultivation system, consisting of thermophilic strain M5 which efficiently releases xylose from xylan for further biofuel and biochemicals synthesis.

\section{Discussion}

In this study, the newly isolated thermophilic Thermoanaerobacterium sp. M5 shows capability of both xylan degradation and butanol biosynthesis. This represents the first report of biosynthesis of butanol from xylan via CBP under thermophilic conditions, which is supported by the following: (i) high xylanase $(0.26 \mathrm{U} / \mathrm{mg})$ and xylosidase $(3.81 \mathrm{U} / \mathrm{mg})$ activities could be detected when using xylan as the sole carbon source; (ii) key enzymes conducting xylan degradation (mainly xylanase and xylosidase) and butanol formation (mainly AdhE) were indentified by LC-MS/MS; (iii) $1.17 \mathrm{~g} / \mathrm{L}$ of butanol was obtained from $30 \mathrm{~g} / \mathrm{L}$ of xylan through CBP, and the highest $8.34 \mathrm{~g} / \mathrm{L}$ of butanol occurred from $60 \mathrm{~g} / \mathrm{L}$ of xylan by co-cultivation with solventogenic $C$. acetobutylicum $\mathrm{NJ} 4$, which was the highest butanol production from xylan through CBP (Table 4) [32]. Moreover, the acetone-uncoupled production within Thermoanaerobacterium sp. M5 suggests that the acetone metabolic pathway may be deficient or blocked. Indeed, the acetoacetate decarboxylase ( $a d c)$ gene catalyzing the conversion of acetoacetate into acetone was eliminated in the genome of strain M5, which is the last step in the acetone formation pathway. This acetone-uncoupled $\mathrm{BE}$ fermentation pathway could further reduce the subsequent cost of separation. These metabolic properties of strain M5 could greatly improve the economic viability of biobutanol production both in terms of the associated substrate costs, by-products and the downstream separation complexities.

Biobutanol was generally produced by solventogenic Clostridium sp. in the traditional $\mathrm{ABE}$ fermentation with the mass ratio of 3:6:1. However, it was found that strain M5 produced higher ethanol over butanol. For example, under optimized $\mathrm{pH}$ conditions, $0.60 \mathrm{~g} / \mathrm{L}$ of butanol occurred with $2.27 \mathrm{~g} / \mathrm{L}$ of ethanol (Table 3 ). It is known that the reducing power is a limiting factor for butanol production, as 4 mol $\mathrm{NAD}(\mathrm{P}) \mathrm{H}$ will be required for $1 \mathrm{~mol}$ butanol production with 2 mol $\mathrm{NAD}(\mathrm{P}) \mathrm{H}$ generation from $1 \mathrm{~mol}$ glucose or $1.2 \mathrm{~mol}$ xylose (Fig. 5). Generally, electron carriers could inhibit hydrogenase in the electron transport shuttle system to overproduce NADH; hence, supplementation of exogenous electrons carriers could improve the NAD(P)H pool size in vivo, thus further driving toward butanol production [33]. Comprehensive studies have been carried out to improve butanol production by using this method [34-36]. For example, Jiang et al. have produced $6.09 \mathrm{~g} / \mathrm{L}$ butanol with $20.89 \%$ increased yield through extra addition of $0.79 \mathrm{~g} / \mathrm{L} \mathrm{NR}$ [37]. In most of the studies, MV replaces the functions of ferredoxin as a better substrate for ferredoxin-NAD $(\mathrm{P})^{+}$ reductase, creating an artificial electron transport chain [38]. However, in strain M5, MV, also known as a commercial herbicide "paraquat", did not help improve butanol production due to a certain inhibition of bacterial growth. Instead, NR shows lower inhibition compared to MV and could significantly improve butanol production. On the other hand, butanol production was also improved notably with addition of $\mathrm{Fe}^{2+}$, because ferredoxin could be properly synthesized due to iron existence, which indicates that $\mathrm{Fe}^{2+}$ could enhance butanol production maybe because of NADH level improvement.

Table 4 Comparision of butanol production by wild-type and genetically engineered thermophilic bacteria

\begin{tabular}{|c|c|c|c|c|}
\hline Strain & Description & Substrate & Titer $(g / L)$ & References \\
\hline T. saccharolyticum JW/SL-YS485 & Wild type & Xylose & 0 & {$[12]$} \\
\hline T. saccharolyticum JW/SL-YS485 & Integration of butanol synthetic way in the wild type & Xylose & 0.85 & {$[12]$} \\
\hline T. saccharolyticum JW/SL-YS485 & Integration of butanol synthetic way in the lactate-deficient strain & Xylose & 1.05 & {$[12]$} \\
\hline T. thermosaccharolyticum DSM 571 & $\begin{array}{l}\text { Overexpression of the butyryl-CoA formation ( } t h l, h b d, c r t, b c d, \text { etfA, and } \\
\text { etfB) }\end{array}$ & Xylose & 0.38 & {$[20]$} \\
\hline T. thermosaccharolyticum W16 & Wild type & Corn stover & 0.074 & {$[11]$} \\
\hline Thermoanaerobacterium sp. M5 & Wild type & Xylan & $1.17 \mathrm{~g} / \mathrm{L}$ & This study \\
\hline
\end{tabular}




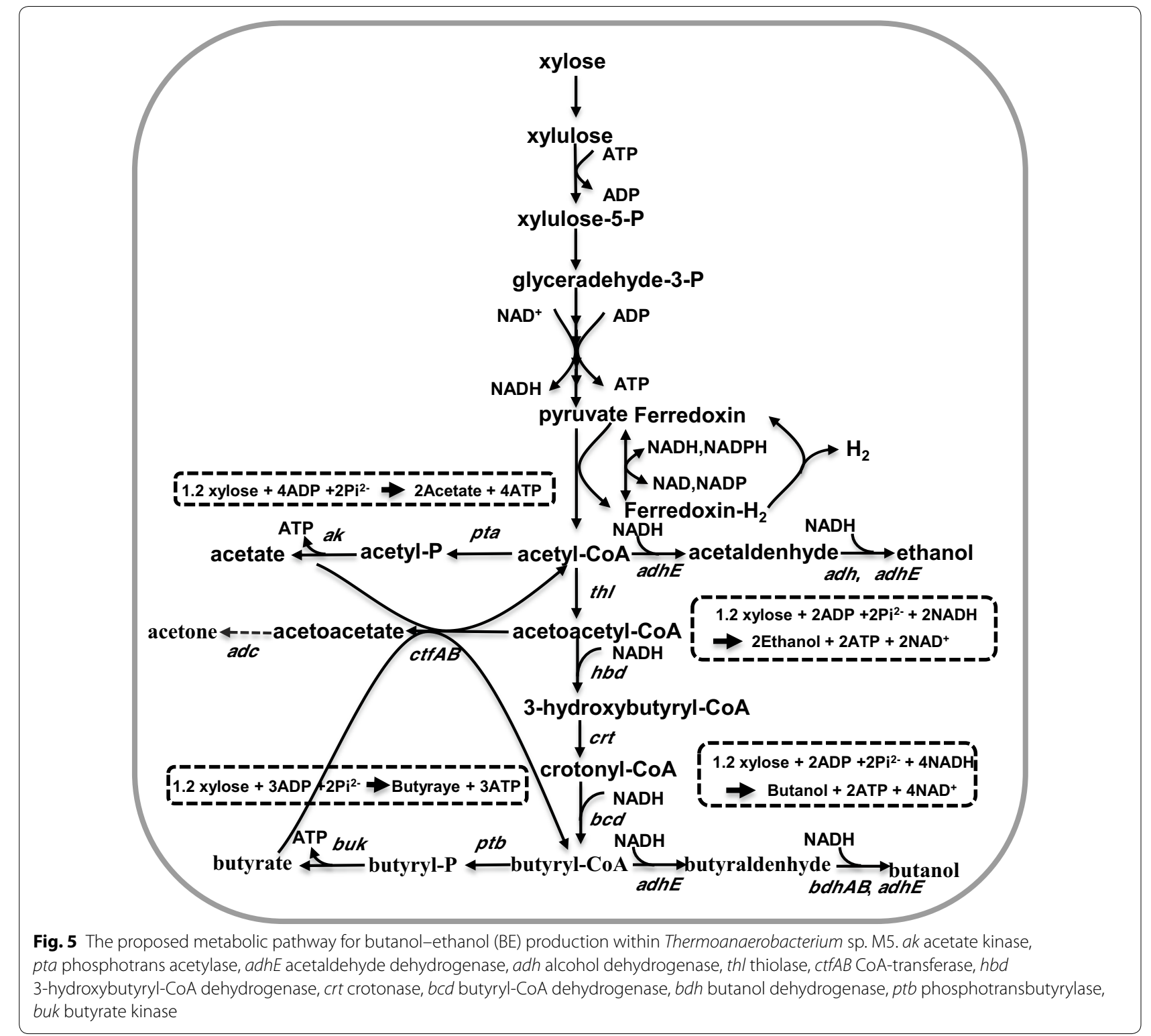

CBP has been considered to be the ideal solution for cost-effective hydrolysis and fermentation of lignocellulosic biomass into biofuels [39]. Unlike most of the solventogenic Clostridium species, the strain M5 shows capability of direct butanol and ethanol production under thermophilic conditions from polysaccharides, such as xylan, representing another reported wild-type solventogenic species which could directly convert xylan to butanol (Table 4). The success of butanol production via CBP was attributed to both its efficient secretion of xylan-degrading enzymes, such as xylanase and $\beta$-xylosidase, and the existence of the butanol synthetic pathway (Fig. 5). Actually, through overexpression of genes responsible for butanol formation (thl, $h b d, c r t$, $b c d$, etfA, and etfB) in wild-type thermophilic T. thermosaccharolyticum DSM571, $0.38 \mathrm{~g} / \mathrm{L}$ of butanol was obtained from xylose [20]. In our study, a higher $1.17 \mathrm{~g} / \mathrm{L}$ of butanol was produced from xylan after fermentation optimization by strain M5 compared to the previous study; however, butanol production was still much lower than that using monosubstrates as the carbon sources by Clostridium strains. Instead, more ethanol and VFAs were produced, especially using polysaccharides as the substrate. The reason could be due to the weak driven carbon flux toward butanol formation. Similar results were also obtained from cellulose when using genetically engineered cellulolytic strains. For example, metabolic construct of cellulolytic C. cellulovorans after 
introduction of the $a d h E 2$ gene could only produce a low amount of butanol $(1.6 \mathrm{~g} / \mathrm{L})$ from cellulose [40]. Nevertheless, a high xylose production of $17.6 \mathrm{~g} / \mathrm{L}$, and stable xylanase $(0.58 \mathrm{U} / \mathrm{mL})$ and $\beta$-xylosidase $(7.69 \mathrm{U} / \mathrm{mL})$ activities still occurred when using $60 \mathrm{~g} / \mathrm{L}$ of xylan as the substrate by strain M5. Based on this characteristics, setting up a co-cultivation system with another solventogenic strain is an efficient and simple strategy to further promote butanol production. Indeed, C. acetobutylicum NJ4 could further accelerate xylose utilization and drive carbon flux toward butanol production. The final butanol production was improved to $8.34 \mathrm{~g} / \mathrm{L}$, which is higher than the highest report of $7.9 \mathrm{~g} / \mathrm{L}$ butanol from cellulose using co-cultivation systems containing $C$. thermocellum and C. saccharoperbutylacetonicum N1-4 [41]. It should be noticed that butyric acid generated before the inoculation of strain NJ4 could also trigger butanol production, as the intracellular and/or extracellular levels of butyric acid are implicated in the induction of solventogenesis in C. acetobutylicum [42]. However, further studies are still needed to improve the final titer through overexpression of $a d h E$ in vivo in strain M5 and elimination of the byproducts pathway simultaneously.

\section{Conclusion}

The newly isolated Thermoanaerobacterium sp. M5 could be regarded as a potential candidate for butanol production from xylan via the CBP process under thermophilic conditions without detectable acetone. The wild-type strain M5 possesses the capacity of efficient xylan utilization through secretion of xylanases and $\beta$-xylosidases, and $1.17 \mathrm{~g} / \mathrm{L}$ of butanol was also obtained from xylan after optimizing the fermentation conditions based on the characteristics of AhdE. The characterized thermostable butanol-producing key enzyme, AdhE in strain M5, is the sole enzyme responsible for butanol formation, which has the activity of aldehyde dehydrogenase in vitro. In addition, due to the limiting capacity of butanol production for strain M5, the co-cultivation system consisting of Thermoanaerobacterium sp. M5 and C. acetobutylicum NJ4 was established and the final butanol production was significantly improved to $8.34 \mathrm{~g} / \mathrm{L}$. The results of this study offer fundamental knowledge for further improvement of butanol production in thermophiles, and the limited factors of butanol-producing metabolic pathway for strain M5 should also be further studied.

\section{Abbreviations}

CBP: consolidated bioprocessing; AdhE: bifunctional alcohol/aldehyde dehydrogenase; BE: butanol-ethanol; $\mathrm{ABE}$ : acetone-butanol-ethanol; $\mathrm{BDH}$ : butanol dehydrogenase; CBMs: carbohydrate-binding modules; $\mathrm{ADH}$ : alcohol dehydrogenase; ALDH: aldehyde dehydrogenase; AEC: artificial electron carriers; NR: neutral red; MV: methyl viologen.

\section{Authors' contributions}

JM and XFX designed the experiments; JYJ, GD, LJS, YW and ZWM performed the experiments; GD, PD, DWL, XFX and MJF analyzed the data; JYJ and XFX wrote the paper; GD, PD and JM revised the paper. All authors read and approved the final manuscript.

\section{Author details}

${ }^{1}$ State Key Laboratory of Materials-Oriented Chemical Engineering, College of Biotechnology and Pharmaceutical Engineering, Nanjing Tech University, Puzhu South Road 30\#, Nanjing 211800, People's Republic of China. ${ }^{2}$ Jiangsu National Synergetic Innovation Center for Advanced Materials (SICAM), Nanjing Tech University, Nanjing 211800, People's Republic of China. ${ }^{3}$ Institute of Microbiology and Biotechnology, University of Ulm, 89069 Ulm, Germany.

\section{Acknowledgements}

Not applicable.

\section{Competing interests}

The authors declare that they have no competing interest.

\section{Availability of data and materials}

The nucleotide sequence of culture M5 was deposited in the GenBank under an accession number of MF405082.1. The genomic sequence of strain M5 was deposited under the GenBank Accession No. of NDHF00000000. All other data generated or analyzed during this study are included in this published article and its Additional information files.

\section{Consent for publication}

All authors consent to the publication.

\section{Ethics approval and consent to participate} Not applicable.

\section{Funding}

This work was supported by the Jiangsu Province Natural Science Foundation for Youths (No. BK20170993), the National Natural Science Foundation of China (Nos. 21706125, 21727818, 21706124, 31700092), the Jiangsu Synergetic Innovation Center for Advanced Bio-Manufacture, Foundation of Guangdong Provincial Key Laboratory of Marine Biotechnology (No. GPKLMB201702) and the Project of State Key Laboratory of Materials-Oriented Chemical Engineering (KL16-08).

\section{Publisher's Note}

Springer Nature remains neutral with regard to jurisdictional claims in published maps and institutional affiliations.

Received: 18 January 2018 Accepted: 21 March 2018

Published online: 02 April 2018

\section{References}

1. Jin C, Yao M, Liu H, Lee CFF, Ji J. Progress in the production and application of $\mathrm{n}$-butanol as a biofuel. Renew Sust Energ Rev. 2011;15(8):4080-106.

2. Zheng T, Olson DG, Tian L, Bomble YJ, Himmel ME, Lo J, Hon S, Shaw AJ, van Dijken JP, Lynd LR. Cofactor specificity of the bifunctional alcohol and aldehyde dehydrogenase (AdhE) in wild-type and mutant Clostridium thermocellum and Thermoanaerobacterium saccharolyticum. J Bacteriol. 2015;197(15):2610-9.

3. Trindade WRDS, Santos RGD. Review on the characteristics of butanol, its production and use as fuel in internal combustion engines. Renew Sust Energ Rev. 2017:69:642-51.

4. Nguyen S, Ala F, Cardwell C, Cai D, McKindles KM, Lotvola A, Hodges S, Deng Y, Tiquia-Arashiro SM. Isolation and screening of carboxydotrophs isolated from composts and their potential for butanol synthesis. Environ Technol. 2013;34(13-14):1995-2007. 
5. Shukor H, Alshorgani NK, Abdeshahian P, Hamid AA, Anuar N, Rahman NA. Production of butanol by Clostridium saccharoperbutylacetonicum N1-4 from palm kernel cake in acetone-butanol-ethanol fermentation using an empirical model. Bioresour Technol. 2014;170(5):565-73.

6. Díaz VH, Tost GO. Butanol production from lignocellulose by simultaneous fermentation, saccharification, and pervaporation or vacuum evaporation. Bioresour Technol. 2016:218:174-82.

7. Wu YR, Zhang M, Zhong M, Hu Z. Synergistic enzymatic saccharification and fermentation of agar for biohydrogen production. Bioresour Technol. 2017;241:369-73.

8. Qureshi N, Saha BC, Hector RE, Hughes SR, Cotta MA. Butanol production from wheat straw by simultaneous saccharification and fermentation using Clostridium beijerinckii: part I — batch fermentation. Biomass Bioenergy. 2008;32(2):168-75.

9. Mahajan C, Chadha BS, Nain L, Kaur A. Evaluation of glycosyl hydrolases from thermophilic fungi for their potential in bioconversion of alkali and biologically treated Parthenium hysterophorus weed and rice straw into ethanol. Bioresour Technol. 2014;163(7):300-7.

10. Gaida SM, Liedtke A, Jentges AHW, Engels B, Jennewein S. Metabolic engineering of clostridium cellulolyticum for the production of n-butanol from crystalline cellulose. Microb Cell Fact. 2016;15(1):6.

11. Ren NQ, Cao GL, Guo WQ, Wang AJ, Zhu YH, Liu BF, Xu JF. Biological hydrogen production from corn stover by moderately thermophile Thermoanaerobacterium thermosaccharolyticum W16. Int J Hydrogen Energy. 2010;35(7):2708-12.

12. Bhandiwad A, Shaw AJ, Guss A, Guseva A, Bahl H, Lynd LR. Metabolic engineering of Thermoanaerobacterium saccharolyticum for n-butanol production. Metab Eng. 2014;21(1):17-25.

13. Tukacshájos A, Pap B, Maróti G, Szendefy J, SzabóP Rétfalvi T. Monitoring of thermophilic adaptation of mesophilic anaerobe fermentation of sugar beet pressed pulp. Bioresour Technol. 2014;166:288-94.

14. Shaw AJ, Podkaminer KK, Desai SG, Bardsley JS, Rogers SR, Thorne PG, Hogsett DA, Lynd LR. Metabolic engineering of a thermophilic bacterium to produce ethanol at high yield. Proc Natl Acad Sci USA. 2008;105(37):13769-74.

15. Xin FX, Chen TP, Jiang YJ, Lu JS, Dong WL, Zhang WM, Ma JF, Zhang M, Jiang M. Enhanced biobutanol production with high yield from crude glycerol by acetone uncoupled Clostridium sp. strain CT7. Bioresour Technol. 2017;244(Pt 1):575.

16. O-Thong S, Prasertsan P, Karakashev D, Angelidaki I. Thermophilic fermentative hydrogen production by the newly isolated Thermoanaerobacterium thermosaccharolyticum, PSU-2. Int J Hydrogen Energy. 2008;33(4):1204-14.

17. Jiang YJ, Xin FX, Lu JS, Dong WL, Zhang WM, Zhang M, Wu H, Ma JF, Jiang M. State of the art review of biofuels production from lignocellulose by thermophilic bacteria. Bioresour Technol. 2017:245(Pt B):1498-506.

18. Lisov AV, Belova OV, Lisova ZA, Vinokurova NG, Nagel AS, AndreevaKovalevskaya ZI, Budaeina ZI, Nagornykh MO, Zakharova MV, Shadrin AM, Solonin AS, Leontievsky AA. Xylanases of cellulomonas flavigena: expression, biochemical characterization, and biotechnological potential. AMB Express. 2017;7(1):5.

19. Wang MY, Li ZH, Xu F, Wang LS, Qu YB. Cellulolytic enzyme production and enzymatic hydrolysis for second-generation bioethanol production. Adv Biochem Eng Biotechnol. 2012;128(1):1-24.

20. Bhandiwad A, Shaw AJ, Guss A, Guseva A, Bahl H, Lynd LR. Metabolic engineering of Thermoanaerobacterium thermosaccharolyticum for increased n-butanol production. Adv Appl Microbiol. 2013;3(1):46-51.

21. Lo J, Zheng TY, Hon S, Olson DG, Lynd LR. The bifunctional alcohol and aldehyde dehydrogenase gene, $a d h E$, is necessary for ethanol production in Clostridium thermocellum and Thermoanaerobacterium saccharolyticum. J Bacteriol. 2015;197(8):1386-93.

22. Tan Y, Liu J, Liu Z, Li F. Characterization of two novel butanol dehydrogenases involved in butanol degradation in syngas-utilizing bacterium Clostridium ljungdahlii DSM 13528. J Basic Microbiol. 2014;54(9):996-1004.

23. Fontaine L, Meynialsalles I, Girbal L, Yang XH, Croux C, Soucaille P. Molecular characterization and transcriptional analysis of adhE2, the gene encoding the NADH-dependent aldehyde/alcohol dehydrogenase responsible for butanol production in alcohologenic cultures of Clostridium acetobutylicum ATCC 824. J Bacteriol. 2002;184(3):821-30.

24. Haki GD, Rakshit SK. Developments in industrially important thermostable enzymes: a review. Bioresour Technol. 2003;89(1):17.

25. Ramió-Pujol S, GaniguÉ R, Bañeras L, Colprim J. Incubation at $25^{\circ} \mathrm{C}$ prevents acid crash and enhances alcohol production in Clostridium carboxidivorans P7. Bioresour Technol. 2015;192:296-303.

26. Mermelstein LD, Papoutsakis ET, Petersen DJ, Bennett GN. Metabolic engineering of Clostridium acetobutylicum ATCC 824 for increased solvent production by enhancement of acetone formation enzyme activities using a synthetic acetone operon. Biotechnol Bioeng. 1993;42(9):1053-60.

27. Guo T, Sun B, Min J, Hao W, Du T, Yan T, Wei P, Ouyang PK. Enhancement of butanol production and reducing power using a two-stage controlled-ph strategy in batch culture of Clostridium acetobutylicum, XY16. World J Microbiol Biotechnol. 2012;28(7):2551-8.

28. He AY, Yin CY, Xu H, Kong XP, Xue JW, Zhu J, Jiang M, Wu H. Enhanced butanol production in a microbial electrolysis cell by Clostridium beijerinckii IB4. Bioprocess Biosyst Eng. 2016;39(2):245-54.

29. Richmond C, Han B, Ezeji TC. Stimulatory effects of calcium carbonate on butanol production by solventogenic Clostridium species. Cont J Microbiol. 2011;5(1):18-28

30. Ambarsari HA, Sonomoto K. Enhanced acetone, butanol, and ethanol fermentation by Clostridium saccharoperbutylacetonicum N1-4 (ATCC 13564) in a chemically defined medium: effect of iron and initial $\mathrm{pH}$ on $\mathrm{ABE}$ ratio. Microbiol Indones. 2012;6(4):139-47.

31. Wu YD, Xue C, Chen L, Bai FW. Effect of zinc supplementation on acetonebutanol-ethanol fermentation by Clostridium acetobutylicum. J Biotechnol. 2013;165(1):18-21.

32. Kiyoshi K, Furukawa M, Seyama T, Kadokura T, Nakazato A, Nakayama S. Butanol production from alkali-pretreated rice straw by co-culture of Clostridium thermocellum and Clostridium saccharoperbutylacetonicum. Bioresour Technol. 2015;186:325-8.

33. Li Z, Shi Z, Li X, Li L, Zheng J, Wang Z. Evaluation of high butanol/acetone ratios in abe fermentations with cassava by graph theory and nadh regeneration analysis. Biotechnol Bioprocess Eng. 2013;18(4):759-69.

34. Rao G, Mutharasan R. Alcohol production by Clostridium acetobutylicum induced by methyl viologen. Biotechnol Lett. 1986;8:893-6.

35. Girbal L, Vasconcelos I, Saint-Amans S, Soucaille P. How neutral red modified carbon and electron flow in Clostridium acetobutylicum grown in chemostat culture at neutral pH. FEMS Microbiol Rev. 1995;16:151-62.

36. Nasser AIShorgani NK, Kalil MS, Wan YW, Monirul Hasan CM, Hamid AA. Improvement of the butanol production selectivity and butanol to acetone ratio (B:A) by addition of electron carriers in the batch culture of a new local isolate of Clostridium acetobutylicum YM1. Anaerobe. 2015;36:65-72.

37. Jiang C, Cao GL, Wang ZY, Li Y, Song JZ, Cong H, Zhang JZ, Yang Q. Enhanced butanol production through adding organic acids and neutral red by newly isolated butanol-tolerant bacteria. Appl Biochem Biotech. 2016;180(7):1-12.

38. Durán-Padilla VR, Davila-Vazquez G, Chávez-Vela NA, Tinoco-Valencia JR, Jáuregui-Rincón J. Iron effect on the fermentative metabolism of Clostridium acetobutylicum ATCC 824 using cheese whey as substrate. Biofuel Res J. 2014;1(4):129-33.

39. Yan Y, Basu A, Li TG, He JZ. Direct conversion of xylan to butanol by a wildtype Clostridium species strain G117. Biotechnol Bioeng. 2016;113:1702-10.

40. Wang J, Yang X, Chen CC, Yang ST. Engineering clostridia for butanol production from biorenewable resources: from cells to process integration. Curr Opin Chem Eng. 2014;6:43-54.

41. Nakayama S, Kiyoshi K, Kadokura T, Nakazato A. Butanol production from crystalline cellulose by cocultured Clostridium thermocellum and Clostridium saccharoperbutylacetonicum N1-4. Appl Environ Microbiol. 2011;77(18):6470-5

42. Zhao Y, Hindorff LA, Chuang A, Monroe-Augustus M, Lyristis M, Harrison ML, Rudolph FB, Bennett GN. Expression of a cloned cyclopropane fatty acid synthase gene reduces solvent formation in Clostridium acetobutylicum ATCC 824. Appl Environ Microbiol. 2003;69(5):2831-41. 